\title{
RACIONALIDADE ARGUMENTATIVA:
}

\section{A valorização da controvérsia}

Moisés Olímpio-Ferreira

(IFSP - Instituto Federal de Educação, Ciência e Tecnologia)

Cruzando os tempos, entrecruzada aos mais diversos grupos e sociedades, a Retórica chega à modernidade erguida em diferentes contextos culturais e sociopolíticos e cercada de grande multiplicidade de abordagens sem soluções definitivas. Em meio a tão diferentes interesses não raramente contraditórios, a inúmeros conflitos de diversos graus que põem em questão valores e hierarquias, cabe-lhe contribuir com a apresentação de alternativas para a tomada de decisões, favorecendo, com isso, a coexistência humana. A negociação de um ponto de vista - sem a imposição de verdades evidentes e de deduções retilíneas - é, mais do nunca, necessária. A racionalidade argumentativa se insere no âmbito da racionalidade sociológica, com práticas argumentativas de negociação em atividade pelos usos sociais da linguagem, pelas interações que têm como pano de fundo a sociabilidade. A Retórica, nesse contexto, está na mediação discursiva e social das dissenções, das concepções e decisões éticas. A nossa proposta, a partir da visão de Chaïm Perelman, objetiva pensar a relevância da racionalidade argumentativa como modo de ação social perspectivado. Para isso, apresentaremos os conceitos da Nova Retórica a respeito do papel social da argumentação, aproximando-os da ideia de perspectivação de Rui Grácio. Com esse viés, necessitando justificar as nossas decisões sob condições de incerteza, a Retórica deve remeter a modos práticos de raciocinar, em racionalidade pautada no razoável, em que pesam os juízos de valor para o estabelecimento das preferências e decisões.

Palavras-chave: Retórica; Nova Retórica; Racionalidade Argumentativa. 